\title{
Formation of Superstructure Composed of Modified Cyclodextrins as Molecular "Blocks" in Aqueous Solution with Host-Guest Complexation. Correlation of Chemical Structure of Modified Group with Complexation
}

\author{
Keiko TAKAHASHI, ${ }^{\dagger}$ Koichi ImotANI, and Masahiko KITSUTA \\ Department of Applied Chemistry, Faculty of Engineering, Tokyo Institute of \\ Polytechnics, 1583 Iiyama, Atsugi, Kanagawa 243-0297, Japan
}

(Received September 21, 2000; Accepted December 21, 2000)

\begin{abstract}
N^{\prime}$-tert-Butoxycarbonylmonoamino acid-binding $\beta$-CDs $(\mathbf{1}, \mathbf{2 , 3}, \mathbf{4 , 5})$ and $\alpha$-CD $(\mathbf{6})$ were prepared by DCC coupling. NMR study suggests some of these novel modified CDs that act as host and guest to prefer "pseudo polymer" formation. The length of an arm between the $N^{\prime}$-tert-butoxycarbonyl group and $\mathrm{C} 6$ position on the glucose ring was that of $-\mathrm{NH}-\mathrm{C}_{\alpha}-\mathrm{CO}-\mathrm{NH}-$. Modified $\beta$-CDs having longer arm form intramolecular rather than intermolecular complexes. KEY WORDS $\quad N^{\prime}$-tert-Butoxycarbonylmonoamino Acid-Binding $\beta$-Cyclodextrin / Intermolecular Complex / NMR Titration / Hybrid Complexation / Molecular Blocks /
\end{abstract}

The development of supramolecular chemistry involves more complete control over molecules and supramolecules. Supramolecular chemistry is that discipline of chemistry which involves all intermolecular interactions where covalent bonds are not established between interacting species. The majority of these interactions is of the host-guest type. Cyclodextrins (CDs) have been known to be the most important ones, because they form inclusion complexes with a variety of aromatic compounds in aqueous solution. ${ }^{1}$ Early stages in CD chemistry presented a wide range of chemists with the very impressive concept of a host-guest complex described as a ball in a bottomless pail. Recently, interaction between $\mathrm{CD}$ and macromolecules has been investigated. ${ }^{2}$ Some superstructures that incorporate plural CDs as components have been reported as pseudoroxanes, rotaxanes, polyrotaxanes, ${ }^{3}$ side-chain polyrotaxanes, ${ }^{4}$ catenanes, ${ }^{5}$ and molecular shuttle driven by light ${ }^{6}$ or heat. ${ }^{7}$

A rather unique superstructure has been observed in the solid state for a monosubstituted $\beta$-CD derivative that behaves as host and guest, such that bulky hydrophobic groups intermolecularly enter other CD cavities and helical "polymers" are formed ${ }^{8}$ or such that a $-\mathrm{CH}_{2}$ $\mathrm{NH}\left(\mathrm{CH}_{2}\right)_{6} \mathrm{NH}_{2}$ side chain on the primary face of one molecule enters a cavity of the $\beta$-CD ring of a neighboring molecule. ${ }^{9}$

To compose a more organized system using simply modified CDs, the important factor is the combination of "flexible" groups and "rigid" groups. We prepared "flexible" modified CDs which have an aromatic amino acid and observed location changes of modified groups by 1D and 2D NMR measurements. ${ }^{10}$ Aromatic groups on CD through a flexible arm usually form intramolecular complexes. Potential formation of intramolecular inclusion complexes in other peptide-CD as evidenced by NMR study has been reported. ${ }^{11}$ To expand CD chemistry to realize unique superstructures in the solution for a substituted CD derivative that behaves both as host and as a guest, such that a substituent on the primary face of one molecule enters the cavity of the CD ring of a neigh-

${ }^{\dagger}$ To whom correspondence should be addressed. boring molecule, an aliphatic hydrophobic group, such as the tert-butoxycarbonyl group (Boc group) is introduced CD. This paper reports a molecular assembly like "Blocks" through the formation of intermolecular inclusion complexes in aqueous solution and the correlation between molecular structure and inclusion.

\section{RESULTS AND DISCUSSION}

Spectroscopic Characterization of Mono- $6 \mathrm{~N}\left(\mathrm{~N}^{\prime}\right.$-tertbutoxycarbonyl)amino Acid-Binding $C D s(B C D)$ Series

$\mathrm{B} \beta \mathrm{CDs} \quad\left(\right.$ Figure 1 ), mono- $6 N$ ( $N^{\prime}$-tertbutoxycarbonylglycyl)amino-6-deoxy- $\beta$ - $\mathrm{CD}(\mathbf{1})$, mono- $6 N$ ( $N^{\prime}$-tert-butoxycarbonylglycylglycyl ) amino-6-deoxy- $\beta$ $\mathrm{CD}(2)$, mono- $6 N\left(N^{\prime}\right.$-tert-butoxycarbonylphenylalanyl) amino-6-deoxy- $\beta$-CD ( 3 ), mono-6N ( $N^{\prime}$-tert butoxycarbonylphenylalanylglycyl ) amino-6-deoxy- $\beta$-CD (4) and mono- $6 N\left(N^{\prime}\right.$-tert-butoxycarbonyltriptophanyl) amino-6-deoxy- $\beta-\operatorname{CD}(5)$, were obtained in almost $40 \%$ yield and purified with recrystallization in water. Arms between CD and the Boc group consisted of origo peptides. The number of amino acids has the same long arm. 1, 3, 5, and 6 have the shorter arm (one amino acid), and 2 and 4 have the longer arm (2 amino acids).

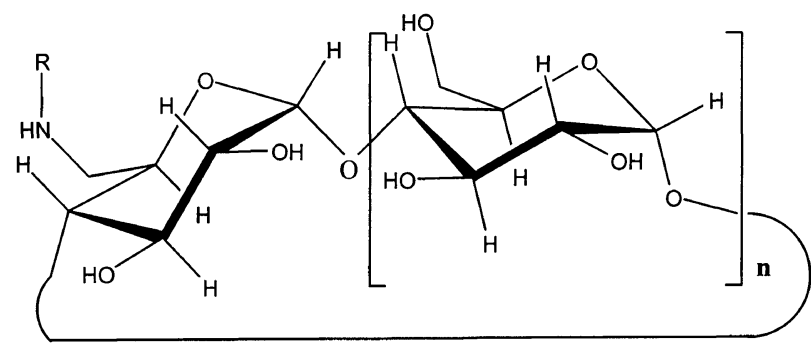

$\begin{array}{lll}\text { R: } 1 & \text { Boc-Gly } & (\mathrm{n}=6) \\ 2 & \text { Boc-GlyGly } & (\mathrm{n}=6) \\ 3 & \text { Boc-Phe } & (\mathrm{n}=6) \\ 4 & \text { Boc-PheGly } & (\mathrm{n}=6) \\ 5 & \text { Boc-Trp } & (\mathrm{n}=6) \\ 6 & \text { Boc-Gly } & (\mathrm{n}=5) \\ 7 & \text { Phe(CHO) } & (\mathrm{n}=6)\end{array}$

Figure 1. Structure of BCD 


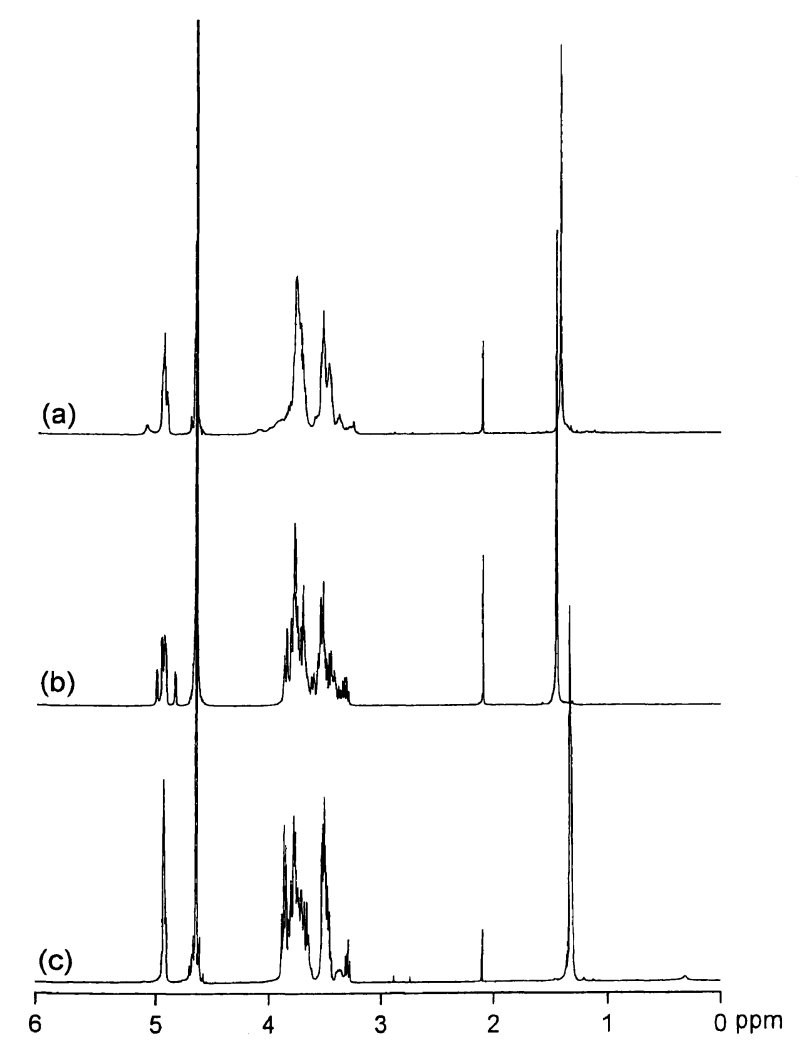

Figure 2. Representative $500 \mathrm{MHz}{ }^{1} \mathrm{H}$ NMR spectra of BCDs in $\mathrm{D}_{2} \mathrm{O}$. (a): 1, (b): $\mathbf{2}$, (c): 6 at room temperature.
The representative ${ }^{1} \mathrm{H}$ NMR spectra are shown in Figure 2. NMR chemical shifts of protons due to CD components are observed as unsplit peak, which is different from previously reported intramolecular complex type modified CDs. ${ }^{10 \mathrm{~b}, \mathrm{f}, \mathrm{h})} \mathrm{CD}$ resonances of $\mathbf{1}, \mathbf{3}$, and $\mathbf{5}$ are observed as broad peaks. NMR chemical shifts of the Boc groups of all the $\mathrm{B} \beta \mathrm{CDs}$ are observed at lower field than that without CD groups. The low-field shift reverts with 1adamantanol (Table I). Broader resonance of $\mathbf{1}, \mathbf{3}$, and 5 was narrowed by adding 1-adamantanol and heating over $80^{\circ} \mathrm{C}$. Direct evidence of the inclusion complex is observed in the NOESY spectra of $\mathrm{B} \beta \mathrm{CD}$ (Figure 3). A

Table I. Chemical shifts of the tert-butoxycarbonyl group with and without 1-adamantanol

\begin{tabular}{lccc}
\hline Compound & Without & $\begin{array}{c}\delta / \text { ppm }^{\mathrm{a}} \\
\text { With }\end{array}$ & $\Delta \delta^{\mathrm{b}}$ \\
\hline $\mathbf{1}$ & 1.406 & 1.326 & 0.080 \\
$\mathbf{2}$ & 1.450 & 1.431 & 0.019 \\
$\mathbf{3}$ & 1.346 & 1.200 & 0.146 \\
$\mathbf{4}$ & 1.395 & 1.385 & 0.010 \\
$\mathbf{5}$ & 1.247 & 1.172 & 0.075 \\
$\mathbf{6}$ & 1.332 & 1.328 & 0.004 \\
BocGly & 1.318 & $-{ }^{\mathrm{b}}$ & - \\
BocPhe & 1.125 & - & - \\
BocTrp & 1.198 & - & - \\
\hline
\end{tabular}

a Conditions; [BocGly] $=57 \mathrm{mM}$, [BocPhe] $=38 \mathrm{mM},[$ BocTrp] $=$ $0.7 \mathrm{mM}, \quad[\mathbf{1}-6]=[1$-adamantanol $]=2.6-2.9 \mathrm{mM}, \quad$ temperature: $27^{\circ} \mathrm{C},{ }^{\mathrm{b}}$ Not examined. b. Difference between $\delta$ value without 1 adamantanol and $\delta$ value with 1-adamantanol.

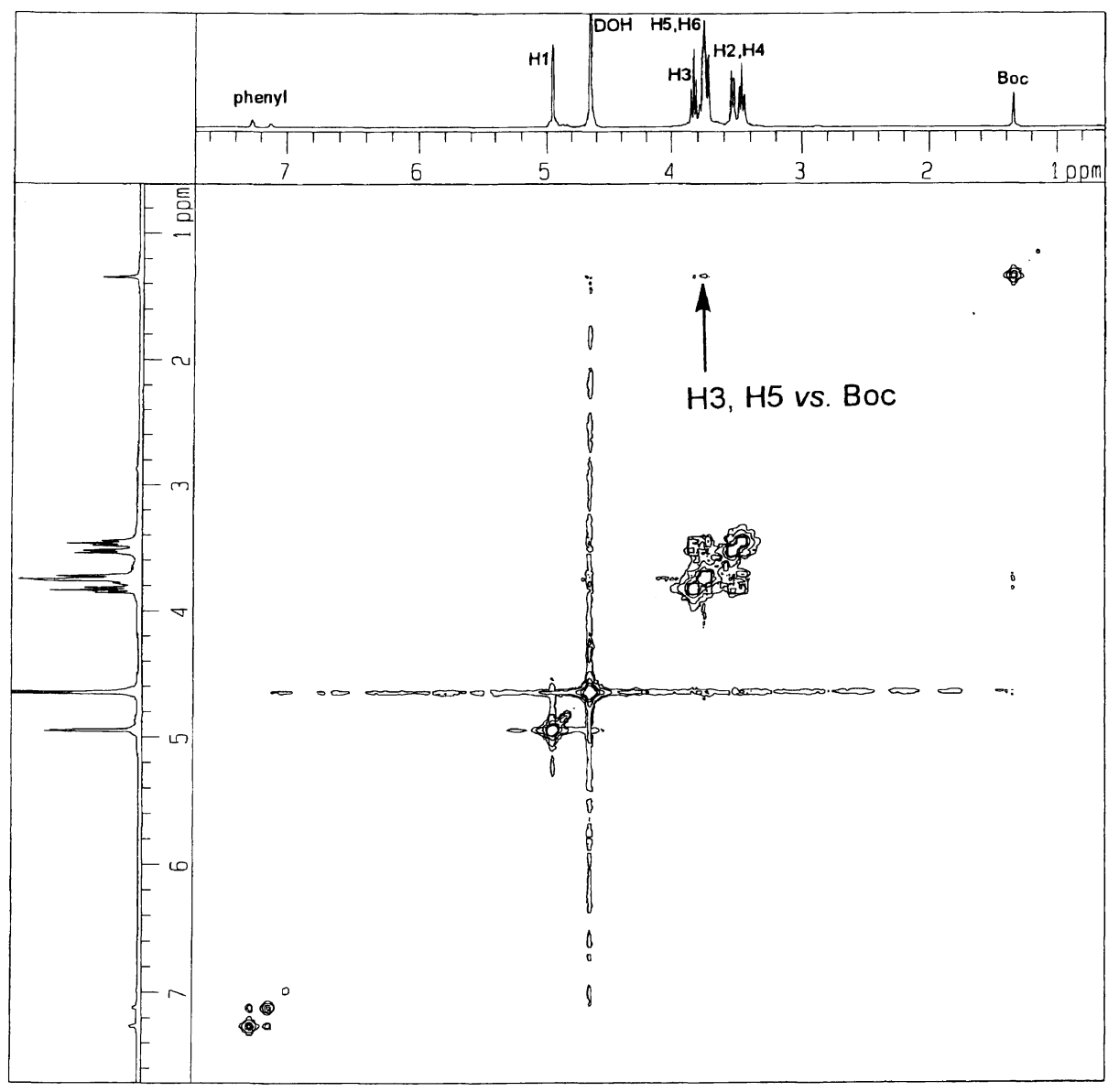

Figure 3. 2D NOESY NMR spectrum of 3 with $\beta$-CD in $\mathrm{D}_{2} \mathrm{O}$. 

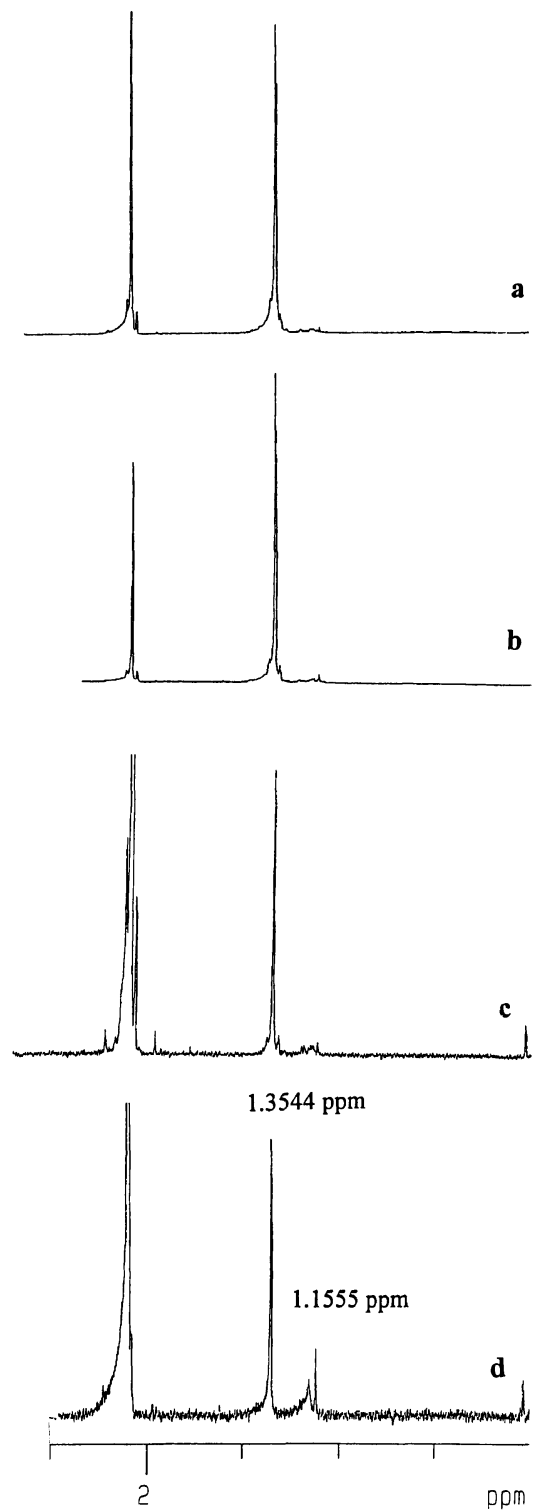

Figure 4. $t$-Butoxy group proton region of $500 \mathrm{MHz}$ NMR spectra of 3 at $2.7 \times 10^{-3} \mathrm{M}$ and at $25^{\circ} \mathrm{C}(\mathrm{a}), 80^{\circ} \mathrm{C}(\mathrm{b})$, and $4.0 \times 10^{-5} \mathrm{M}$ at $25^{\circ} \mathrm{C}(\mathrm{c})$ and $80^{\circ} \mathrm{C}(\mathrm{d})$.

cross peak between the $\mathrm{H} 3$ protons of $\mathrm{CD}$ ring and methylene protons of Boc group was observed. Concentrationdependent changes were observed in the resonances of Boc groups on 1, 3, and 5. Representative data are shown in Figure 4. A single peak of the Boc group on 3 is observed at $1.35 \mathrm{ppm}$ at $2.7 \times 10^{-3} \mathrm{M}$, and two peaks at 1.35 and $1.15 \mathrm{ppm}$ at $4.0 \times 10^{-5} \mathrm{M}$ at $80^{\circ} \mathrm{C}$. The Boc groups of $\mathrm{B} \beta \mathrm{CD}$ may thus be included in $\mathrm{CD}$ cavities and Boc groups on $\mathbf{1}, \mathbf{3}$, and $\mathbf{5}$, in other CD cavities.

\section{Hybrid Complex Formation between BCD and Native $C D s$}

Direct evidence for intermolecular complex formation among modified CDs is given by hybrid complex formation between native $\mathrm{CD}$ and modified CD. ${ }^{8,12}$ Association constants $(K)$ in hybrid dimerization between $\beta$-CD and 6-deoxy-6-( $p$-hydroxy- $m$-nitrophenacetyl)thio- $\beta$-CD or 6-deoxy-6-(4-hydroxy-5-methyl-3-nitrophenacetyl)thio- $\beta$-CD are 282 and $151 \mathrm{M}^{-1}$ respectively, as confirmed by the finding that above monosubstituted CDs

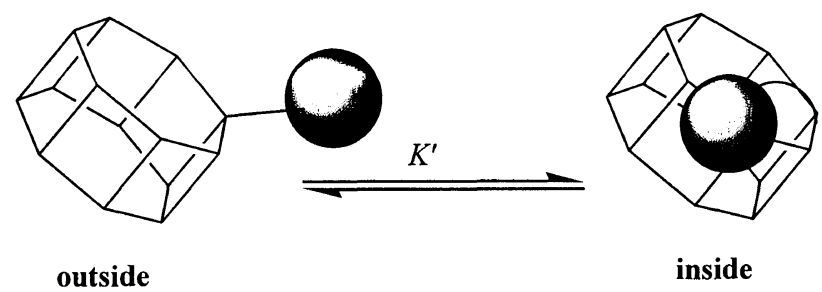

Scheme 1. Equiblium state of intramolecular complex.

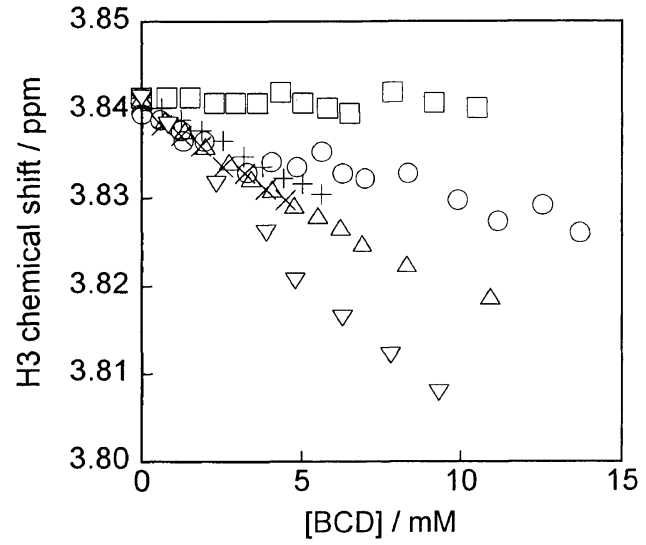

Figure 5. Dependence of H3 chemical shift on concentration of $\mathrm{BCD} ;(\bigcirc): \mathbf{1},(\square): \mathbf{2},(\times): \mathbf{3},(\triangle): \mathbf{5},(\nabla): \mathbf{6}$.

form higher complexes by intermolecular interaction in aqueous solution. ${ }^{8}$ The modified group at the CD stays inside or outside the cavity to maintain equilibrium $\left(K^{\prime}\right.$; Scheme 1). If equilibrium leans to the outside type complexation, the modified group should be included in other CDs to form intramolecular complex. However, in previous reports, $K^{\prime}$ is not mentioned. A native CD (host) and modified CD (guest) are assumed to be in equilibrium with the complex as shown in Scheme 2.

$\mathrm{H} 3$ and H5 protons of glucose composed of a CD ring are located inside the cavity. When a guest molecule enters a cavity, chemical shifts change to high field. Figure 5 shows that chemical shifts of $\mathrm{H} 3$ protons on the native $\mathrm{CD}$ ring depend on the concentration of modified CD. In the absence of BCDs, chemical shifts of the H3 protons of the $\beta$-CD were observed at $3.840 \mathrm{ppm}$. When 1 was added to CD solution, H3 protons shifted to $3.82 \mathrm{ppm}$. When $2,3,4$, or 5 were added to $\beta$-CD solution, highfield shift was observed. The solubility of $\mathbf{3}, \mathbf{4}$, and $\mathbf{5}$ in aqueous solution was too low to achieve saturation. When mono-6-deoxy-6- $N(N$-formylphenyl-alanyl)-amino$\beta-\mathrm{CD}(7)^{10 \mathrm{a}, \mathrm{b}, \mathrm{c}, \mathrm{d})}$ was added to $\beta$-CD solution, no change was observed. $\mathrm{B} \alpha \mathrm{CD}$ and $\mathrm{B} \beta \mathrm{CDs}$ act as guest molecules. When BCDs were added to $\alpha$-CD solution instead of $\beta$ CD solution, no change was observed.

The observed chemical shift $\left(\delta_{\text {obs }}\right)$ of a proton inside the cavity of native CD is a weighted average of that proton chemical shifts in two possible environments, the chemical shift without guest $\left(\delta_{\mathrm{H}}\right)$ and the chemical shift including guest molecules in the $\operatorname{cavity}\left(\delta_{\mathrm{HG}}\right)$. The dependence of change of chemical shift on concentration of the guest molecules gives the association constants between CD and guest. ${ }^{13}$ If initial native CD concentration is defined to be $\mathrm{H}_{0}$ and $\delta$ is the difference in chemical 


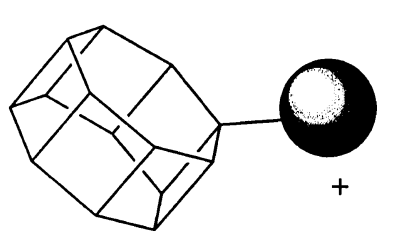

$\mathrm{B}_{\mathrm{n}} \mathrm{CD}$

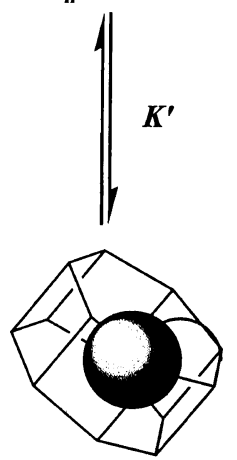

intramolecular complex

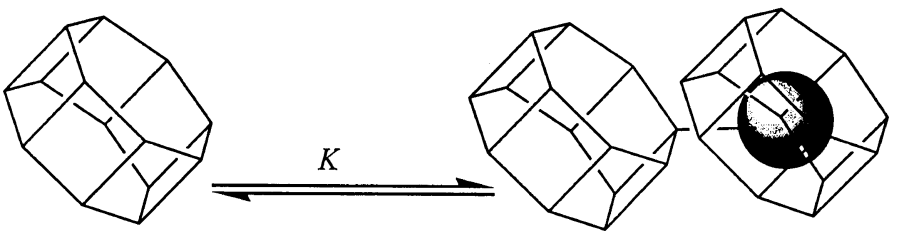

$\beta-\mathbf{C D}$ intermolecular complex

Scheme 2. Formation of intra- and intermolecular complex.

shifts for two conditions $\left(\delta_{\mathrm{HG}}-\delta_{\mathrm{H}}\right)$, the following equation applies:

$$
\delta_{\text {obs }}=\delta_{\mathrm{H}}+\delta \times[\mathrm{HG}] / \mathrm{H}_{0}
$$

Chemical shift is determined by the extent of complexation. The concentration of the complex may be exactly calculated. Combining the above equations gives an exact expression for the observed chemical shift as a function of $\mathrm{H}_{0}, \mathrm{G}_{0}, \delta, K$, and $K^{\prime}$.

$$
\begin{aligned}
\Delta \delta=\frac{\delta}{2} \times\left[1+\frac{\mathrm{G}_{0}}{\mathrm{H}_{0}}\right. & +\frac{1}{\left(\frac{K}{1+K^{\prime}} \mathrm{H}_{0}\right)} \\
& -\sqrt{\left.\mid 1+\frac{\mathrm{G}_{0}}{\mathrm{H}_{0}}+\frac{1}{\left.\left(\frac{K}{1+K^{\prime}}\right) \mathrm{H}_{0}\right)^{2}-\frac{4 \mathrm{G}_{0}}{\mathrm{H}_{0}}}\right]}
\end{aligned}
$$

By the NMR titration as shown in Scheme 2, the modified association constants $\left(K / K^{\prime}+1\right)$ between $\beta$-CD or $\alpha$ $\mathrm{CD}$ and $1,2, \mathbf{3}, \mathbf{4}, \mathbf{5}, \mathbf{6}$ or $\mathbf{7}$ were calculated as shown in Table II. Association constants $(K)$ of the complexes formed between $\alpha-, \beta$-, and $\gamma$-CDs and alkyl units of water soluble copolymers of acrylamide with methacrylates have been reported. ${ }^{14}$ The association constant between $\alpha$-, $\beta$-, and $\gamma$-CDs and tert-butyl group copolymers is almost 0,340 , and $57 \mathrm{M}^{-1}$, respectively. The $(K /$ $\left.K^{\prime}+1\right)$ values between $\alpha-\mathrm{CD}$ and 1 , or 6 were reasonable. The reason why the total association constants, $(K /$ $K^{\prime}+1$ ), in Table II are smaller than $K$ previously reported may be the conformational effect of CD group and existence of intramolecular complex formation $\left(K^{\prime}\right) . \alpha$ $\mathrm{CD}$ cannot include the Boc group. Chemical shift due to the $\mathrm{H} 5$ proton, situated near the narrow side of the cavity, slightly changed. Boc groups of $1,3,5$, and 6 may thus be included from the wider rim of the cavity of $\beta$ CD.
Table II. Modified association constants between native CDs and modified-CDs

\begin{tabular}{cclc}
\hline Native CD & Modified CD & Amino acid & $K /\left(1+K^{\prime}\right) / \mathrm{M}^{-1}$ \\
\hline$\alpha$-CD & $\mathbf{6}$ & Gly & 0 \\
$\alpha$-CD & $\mathbf{1}$ & Gly & 0 \\
$\beta$-CD & $\mathbf{6}$ & Gly & $133 \pm 2$ \\
$\beta$-CD & $\mathbf{1}$ & Gly & $82 \pm 1$ \\
$\beta$-CD & $\mathbf{2}$ & GlyGly & $4 \pm 2$ \\
$\beta$-CD & $\mathbf{3}$ & Phe & $98 \pm 2$ \\
$\beta$-CD & $\mathbf{4}$ & PheGly & $7 \pm 1$ \\
$\beta$-CD & $\mathbf{5}$ & Trp & $98 \pm 3$ \\
$\beta$-CD & $\mathbf{7}$ & Phe & 0 \\
\hline
\end{tabular}

Supramolecular Formation of "Molecular Blocks"

The broader resonance of 1,3 , and 5 narrowed and water solubilities of $\mathbf{1}, \mathbf{3}$, and $\mathbf{5}$ increased in the presence of $\beta$-CD. Concentration dependency was observed. Boc groups of $\mathbf{1}, \mathbf{3}$, and 5 are included in other $\mathrm{B} \beta \mathrm{CD}$ cavity like "blocks" in aqueous solution. Boc groups at the 2 and $\mathbf{4}$ are included in its cavity and form intramolecular complexes similar to 7 .

\section{Chromophores Attached BCDs in Molecular Blocks}

Compounds 3, 4, and 5 have two hydrophobic groups, one is Boc group and the other is aromatic group. Mono$6 N\left(N^{\prime}\right.$-formylphenylalanyl ) amino-6-deoxy- $\beta$-CD ( 7 ), mono- $6 N$-phenylalanylamino-6-deoxy- $\beta$-CD (8), mono-6 $N$ ( $N^{\prime}$-formylphenylalanylglycyl ) amino-6-deoxy- $\beta$-CD (9), mono-6N-phenylalanylglycyl-amino-6-deoxy- $\beta$-CD (10) and mono-6N-tryptophanylamino-6-deoxy- $\beta$-CD (11) form strong intramolecular self-inclusion complexes in aqueous solution. ${ }^{10,11}$ In the absence of the Boc group, the aromatic group interacts to self hydrophobic cavity. In the presence of Boc group, the Boc group enters other CD cavity to form intermolecular complexes. Compound $\mathbf{3}, \mathbf{4}$, and 5 have chromophores which may be included in CD cavities as guest groups. The fluorescence intensity of a chromophore in the CD cavity is usually stronger than that of a free chromophore, because of the hydro- 
Table III. Quantum yields in water

\begin{tabular}{lc}
\hline Compound & Quantum Yield $^{\mathrm{a}}$ \\
\hline $\mathbf{3}$ & 0.04 \\
$\mathbf{4}$ & 0.03 \\
BocPhe & 0.03 \\
$\mathbf{5}$ & 0.23 \\
BocTrp & 0.23 \\
\hline
\end{tabular}

${ }^{a}$ Fluorescence spectra snd Adsorption spectra were measured at $25^{\circ} \mathrm{C}$. Excitation wavelength is $260 \mathrm{~nm}$. Quantum yields were calculated by integration of area of emission spectra and absorbance of modified CD and (-) quinine sulfate dihydrate as standard.

phobic environment of the cavity. ${ }^{10}$ Quantum yields of $\mathbf{3}$, $\mathbf{4}$, and $\mathbf{5}$ in an aqueous solution are shown in Table III. All chromophores attached to CDs were nearby the same as without CD. The edge effect, ${ }^{15}$ which indicates that a chromophore stays around the "edge" between hydrophobic and hydrophilic areas, was not observed at excitation wavelengths from $250 \mathrm{~nm}$ to $320 \mathrm{~nm}$. Phenyl groups of $\mathbf{3}, \mathbf{4}$, and $\mathbf{5}$ should be embedded in the hydrophilic environment not in CD cavities. NMR resonances of aromatic groups in $\mathbf{3}$ and $\mathbf{4}$ are almost the same as those of Phe and PheGly. No concentration-dependent changes were observed in the resonances of aromatic group at the $\mathrm{B} \beta \mathrm{CD}$ concentration of $3 \times 10^{-3} \mathrm{M}$ to $4 \times$ $10^{-5} \mathrm{M}$ at $25-80^{\circ} \mathrm{C}$. From these results, aromatic groups stay in hydrophilic environment and not in CD cavities.

\section{CONCLUSION}

$N^{\prime}$-tert-Butoxycarbonylmonoamino acid-binding $\beta$ CDs, such as 1, 3, and 5 prefer to form intermolecular complexes. The length of an arm between the $N^{\prime}$-tertbutoxycarbonyl group and the $\mathrm{C} 6$ position on the glucose ring was that of $-\mathrm{NH}-\mathrm{C}_{\alpha}-\mathrm{CO}-\mathrm{NH}-$. Modified CDs having a longer arm, 2 and 4, form intramolecular rather than intermolecular complexes. 1, 3, and $\mathbf{5}$ form "pseudo polymers" with inclusion phenomenon.

\section{EXPERIMENTAL}

\section{Measurement}

NMR spectra were measured on a JEOL Lambda 500 spectrometer $\left(500 \mathrm{MH}_{\mathrm{Z}}\right)$ in $\mathrm{D}_{2} \mathrm{O}$ using acetone as internal reference $(2.100 \mathrm{ppm}$ ) at room temperature ROESY spectra were measured with mixing times of $500 \mathrm{~ms}$. Modified association constants $\left(K /\left(K^{\prime}+1\right)\right)$ between modified CD and $\beta$-CD were estimated NMR titration at $25^{\circ} \mathrm{C}$. Fluorescence spectra were taken on a JASCO FP770 .

\section{Preparation of Modified CDs}

BCDs were prepared from 6-amino-6-deoxy- $\beta$-CD and $N$-tert-butoxycarbonylamino acid in DMF with $N, N$ dicyclohexylcarbodiimide (DCC) as previously reported method. ${ }^{10}$

\section{Mono-6 $N$ - $\left(N^{\prime}\right.$-tert-butoxycarbonylglycyl)amino-6-deoxy- $\beta-C D(1)$}

$N$-tert-butoxycarbonylglycine $(175 \mathrm{mg}, 1.0 \mathrm{mmol})$ and DCC (206 mg, $1.0 \mathrm{mmol})$ were dissolved in DMF (1 mL) and stirred $7 \mathrm{~min}$ at $2^{\circ} \mathrm{C}$. ACD (576 mg, $\left.0.5 \mathrm{mmoL}\right)$ in 3 $\mathrm{mL}$ of DMF was added to the solution with stirring and reacted for $1 \mathrm{~h}$ at $2^{\circ} \mathrm{C}$ and $2 \mathrm{~h}$ at room temperature. After the usual treatment, reprecipitation to acetone was done, giving the crude product. This crude product was purified by recrystallization from water, and the product was obtained as white powder $(471 \mathrm{mg}, 73 \%)$. Rf, 0.48 (butanol/ethanol/ $\mathrm{H}_{2} \mathrm{O}=5 / 4 / 3$ ). Elemental analysis, (Found: $\mathrm{C}, 42.90 ; \mathrm{H}, 6.86 ; \mathrm{N}, 2.08 . \mathrm{C}_{52} \mathrm{H}_{82} \mathrm{O}_{37} \mathrm{~N}_{2} \cdot 4 \mathrm{H}_{2} \mathrm{O}$ requires $\mathrm{C}, 43.17 ; \mathrm{H}, 6.66 ; \mathrm{N}, 2.06 \%) .{ }^{1} \mathrm{H} \mathrm{NMR}\left(500 \mathrm{MHz}, \mathrm{D}_{2}\right.$ $\mathrm{O}, \mathrm{ppm}): \delta 1.40$ (s,9H,tert-butyl), 3.25-4.09 (br, $44 \mathrm{H}, \mathrm{H}$ 2 , $\mathrm{H} 3, \mathrm{H} 4, \mathrm{H} 5$, and $\mathrm{H} 6$ of $\beta-\mathrm{CD}$ and $-\mathrm{CH}_{2}-$ of glycine), $4.91-5.08$ (br, $7 \mathrm{H}, \mathrm{O}^{-}-1 \mathrm{H}$ of $\left.\left.\beta-\mathrm{CD}\right), \mathrm{MS} \mathrm{FAB}^{-}\right) \mathrm{m} / \mathrm{Z}$, 1290.

\section{Mono-6N ( $N^{\prime}$-tert-butoxycarbonylglycyl ) amino-6-deoxy-} $\alpha-C D(6)$

This compound was synthesized and isolated in the same manner as 1 using 6-amino-6-deoxy- $\alpha$-CD and $N$ tert-butoxycarbonylglycine. Yield 72\%; Rf, 0.54 (butanol/ ethanol/ $\mathrm{H}_{2} \mathrm{O}=5 / 4 / 3$ ). Elemental analysis, (Found: $\mathrm{C}, 43.36 ; \mathrm{H}, 6.24 ; \mathrm{N}, 1.89 . \quad \mathrm{C}_{52} \mathrm{H}_{80} \mathrm{O}_{37} \mathrm{~N}_{2} \cdot 6 \mathrm{H}_{2} \mathrm{O}$ requires $\mathrm{C}, 43.57 ; \mathrm{H}, 6.47 ; \mathrm{N}, 1.96 \%) .{ }^{1} \mathrm{H}$ NMR $\left(500 \mathrm{MHz}, \mathrm{D}_{2} \mathrm{O}\right.$, ppm): $\delta 1.33$ (s, $9 \mathrm{H}$, tert-butyl), 3.27-3.88 (br, 38H, H2, $\mathrm{H} 3, \mathrm{H} 4, \mathrm{H} 5$, and $\mathrm{H} 6$ of $\alpha-\mathrm{CD}$ and $-\mathrm{CH}_{2}-$ of glycine), 4.92 $-4.93\left(6 \mathrm{H}, \mathrm{O}^{-}-\mathrm{H}\right.$ of $\left.\left.\alpha-\mathrm{CD}\right), \mathrm{MS} \mathrm{FAB}^{-}\right) \mathrm{m} / \mathrm{Z}, 1128$.

\section{Mono-6N ( $N^{\prime}$-tert-butoxycarbonylglycylglycyl) amino-6- deoxy- $\beta-C D(2)$}

This compound was synthesized and isolated in the same manner as 1 using ACD and $N$-tertbutoxycarbonyglycylglycine. Yield 87\%; Rf, 0.36 (butanol/ethanol/ $\mathrm{H}_{2} \mathrm{O}=5 / 4 / 3$ ). Elemental analysis, (Found: $\mathrm{C}, 43.33 ; \mathrm{H}, 6.56 ; \mathrm{N}, 3.14 . \quad \mathrm{C}_{51} \mathrm{H}_{85} \mathrm{O}_{38} \mathrm{~N}_{3} \cdot 2 \mathrm{H}_{2} \mathrm{O}$ requires $\mathrm{C}, 44.25 ; \mathrm{H}, 6.48 ; \mathrm{N}, 3.04 \%) .{ }^{1} \mathrm{H}$ NMR $\left(500 \mathrm{MHz}, \mathrm{D}_{2} \mathrm{O}\right.$, $\mathrm{ppm}): \delta 1.45$ (s, $9 \mathrm{H}$, tert-butyl), 3.29-3.87 (br, $42 \mathrm{H}, \mathrm{H} 2$, $\mathrm{H} 3, \mathrm{H} 4, \mathrm{H} 5$, and $\mathrm{H} 6$ of $\beta-\mathrm{CD}$ and $4 \mathrm{H}-\mathrm{CH}_{2}-$ of glycine), $4.84-5.00\left(7 \mathrm{H}, \mathrm{O}^{-}-1 \mathrm{H}\right.$ of $\beta$-CD), $\mathrm{MS}\left(\mathrm{FAB}^{-}\right) \mathrm{m} / \mathrm{Z}, 1347$.

Mono-6N( $N^{\prime}$-tert-butoxycarbonylphenylalanyl) amino-6deoxy- $\beta-C D(3)$

This compound was synthesized and isolated in the same manner as 1 using ACD and $N$-tertbutoxycarbonyphenylalanine. Yield 74\%; Rf,56 (butanol/ ethanol $/ \mathrm{H}_{2} \mathrm{O}=5 / 4 / 3$ ). Elemental analysis, (Found: $\mathrm{C}, 46.88 ; \mathrm{H}, 6.82 ; \mathrm{N}, 1.91 . \quad \mathrm{C}_{56} \mathrm{H}_{88} \mathrm{O}_{37} \mathrm{~N}_{2} \cdot 3 \mathrm{H}_{2} \mathrm{O}$ requires $\mathrm{C}, 46.86 ; \mathrm{H}, 6.60 ; \mathrm{N}, 1.95 \%) .{ }^{1} \mathrm{H}$ NMR $\left(500 \mathrm{MHz}, \mathrm{D}_{2} \mathrm{O}\right.$, ppm): $\delta 1.35$ (s, 9H, tert-butyl), 2.73 and 2.89 (br, $2 \mathrm{H}$, $-\mathrm{CH}_{2}-$ of phenylalanine), 3.36-3.87 (br, $42 \mathrm{H}, \mathrm{H} 2, \mathrm{H} 3$, $\mathrm{H} 4, \mathrm{H} 5$, and $\mathrm{H} 6$ of $\beta$ - $\mathrm{CD}$ and $1 \mathrm{H}-\mathrm{CH}-$ of phenylalanine), $4.88-4.98$ ( $7 \mathrm{H}, \mathrm{O}-1 \mathrm{H}$ of $\beta$-CD), $7.15-7.27$ (br, $5 \mathrm{H}, \mathrm{C}_{6} \mathrm{H}_{5}$ of phenylalanine), $\mathrm{MS}\left(\mathrm{FAB}^{-}\right) \mathrm{m} / \mathrm{Z}, 1380$.

Mono-6N ( $N^{\prime}$-tert-butoxycarbonylphenylalanylglycyl)amino-6-deoxy- $\beta-C D(4)$

This compound was synthesized and isolated in the same manner as 1 using ACD and N-tertbutoxycarbonyphenylalanylglycine. Yield 58\%; Rf, 0.53 (butanol/ethanol/ $\mathrm{H}_{2} \mathrm{O}=5 / 4 / 3$ ). Elemental analysis, (Found: $\mathrm{C}, 45.60 ; \mathrm{H}, 6.63 ; \mathrm{N}, 2.67 . \mathrm{C}_{58} \mathrm{H}_{91} \mathrm{O}_{38} \mathrm{~N}_{3} \cdot 5 \mathrm{H}_{2} \mathrm{O}$ requires $\mathrm{C}, 45.58 ; \mathrm{H}, 6.66 ; \mathrm{N}, 2.75 \%) .{ }^{1} \mathrm{H} \mathrm{NMR}\left(500 \mathrm{MHz}, \mathrm{D}_{2}\right.$ $\mathrm{O}, \mathrm{ppm}): \delta 1.39\left(\mathrm{~s}, 9 \mathrm{H}\right.$, tert-butyl), $2.84\left(\mathrm{t}, 2 \mathrm{H},-\mathrm{CH}_{2}-\right.$ of phenylalanine), 3.28-3.84 $(42 \mathrm{H}, \mathrm{H} 2, \mathrm{H} 3, \mathrm{H} 4, \mathrm{H} 5$, and $\mathrm{H}$ 
6 of $\beta$-CD and $1 \mathrm{H}-\mathrm{CH}-$ of phenylalanine), 3.99 and 4.07 ( $\mathrm{t}, 2 \mathrm{H},-\mathrm{CH}_{2}-$ of phenylalanine), $4.83-4.99(7 \mathrm{H}, \mathrm{O}-1 \mathrm{H}$ of $\beta$-CD), $7.16-7.31$ (br, $5 \mathrm{H}, \mathrm{C}_{6} \mathrm{H}_{5}$ of phenylalanine), MS $\left(\mathrm{FAB}^{-}\right) \mathrm{m} / \mathrm{Z}, 1437$.

Mono-6N ( $N^{\prime}$-tert-butoxycarbonyltryptophanyl ) amino-6deoxy- $\beta-C D(5)$

This compound was synthesized and isolated in the same manner as 1 using ACD and $N$-tertbutoxycarbonytryptophane. Yield 68\%; Rf, 0.59 (butanol/ ethanol/ $\mathrm{H}_{2} \mathrm{O}=5 / 4 / 3$ ). Elemental analysis, (Found: $\mathrm{C}, 45.60 ; \mathrm{H}, 6.63 ; \mathrm{N}, 2.67 . \mathrm{C}_{58} \mathrm{H}_{91} \mathrm{O}_{38} \mathrm{~N}_{3} \cdot 5 \mathrm{H}_{2} \mathrm{O}$ requires $\mathrm{C}, 45.58 ; \mathrm{H}, 6.66 ; \mathrm{N}, 2.75 \%) .{ }^{1} \mathrm{H}$ NMR $\left(500 \mathrm{MHz}, \mathrm{D}_{2} \mathrm{O}\right.$, ppm): $\delta 1.25$ (s, $9 \mathrm{H}$, tert-butyl), 2.91 and 3.09 (br, $2 \mathrm{H}$, $-\mathrm{CH}_{2}-$ of tryptophan), 3.29-3.78 (br, $42 \mathrm{H}, \mathrm{H} 2, \mathrm{H} 3, \mathrm{H} 4$, $\mathrm{H} 5$, and $\mathrm{H} 6$ of $\beta$-CD and $1 \mathrm{H}-\mathrm{CH}-$ of tryptophan), 4.80$5.01(7 \mathrm{H}, \mathrm{O}-1 \mathrm{H}$ of $\beta$-CD), $7.10-7.50$ (br, $5 \mathrm{H}$, indolyl group of tryptophan), $\mathrm{MS}\left(\mathrm{FAB}^{-}\right) \mathrm{m} / \mathrm{Z}, 1419$.

Acknowledgments. The present work was supported by a Grant-in-Aid No.09680579 from the Ministry of Education, Science, Sport, and Culture.

\section{REFERENCES}

1. V. T. D'Souza and K. B. Lipkowitz, Ed., "Cyclodextrins", Chem. Rev., 98 (1998).

2. a) S. A. Nepogodiev and J. F. Stoddart, Chem. Rev., 98, 1956 (1998). b) T. J. Hubin, A. G. Kolchinski, A. L. Vane, and D. H. Busch, 'Template Control of Supramolecular Architecture', in "Advances in Supramolecular Chemistry", G. W. Gokel, Ed., JAI Press Inc., London, 1999, 5, p 237.

3. a) A. Harada, J. Li, and M. Kamachi, Macromolecules, 23, 2821 (1990). b) A. Harada and M. Kamachi, J. Chem. Soc., Chem. Comm ., 1322 (1990). c) A. Harada, J. Li, and M. Kamachi, Nature (London), 356, 325 (1992). d) A. Harada and M. Kamachi, Nature (London), 370, 126 (1994).

4. a) M. Born and H. Ritter, Adv. Mater., 8, 149 (1996). b) I. Yamaguchi, K. Osakada, and T. Yamamoto, Macromolecules, 30, 4288 (1997). c) M. Born, T. Koch, and H. Ritter, Macromol. Chem. Phys., 8, 1761, (1995). d) M. Born and H. Ritter,
Angew. Chem., Int. Ed. Engl., 35, 309 (1995). e) M. Born, T. Koch, and H. Ritter, Acta Polym., 45, 68 (1994).

5. a) A. Lütringhaus, F. Cramer, H. Prinzbach, and F. M. Henglein, Leibigs Ann. Chem., 62, 527 (1958). b) D. Armspach, P. R. Ashton, C. P. Moore, N. Spencer, J. F. Stoddart, T. J. Wear, and D. J. Williams, Angew. Chem., Int. Ed. Engl., 32, 854 (1993). c) D. Armspach, P. R. Ashton, N. Spencer, J. F. Stoddart, and D. J. Williams, Pesticide Sci., 41, 232 (1994). d) D. Armspach, P. R. Ashton, R. Ballardini, V. Balzani, A. Godi, C. P. Moore, L. Prodi, N. Spencer, J. F. Stoddart, M. S. Tolley, and D. J. Williams, Chem. Eur. J., 1, 33 (1995).

6. H. Murakami, A. Kawabuchi, K. Kotoo, M. Kunitake, and N. Nakajima, J. Am. Chem. Soc., 119, 7605 (1997).

7. H. Fujita, T. Ooya, and N. Yui, Macromolecules, 32, 2534 (1999).

8. S. Kamitori, K. Hirotsu, T. Higuchi, K. Fujita, H. Yamamura, T. Imoto, and I. Tabushi, J. Chem. Soc., Perkin Trans. 2, $1987,7$.

9. M. Dimitrius, A. Terzis, A. W. Coleman, and C. de Rango, Carbohydr. Res., 282, 125 (1996).

10. a) K. Takahashi, Y. Ohtsuka, and K. Hattori, Chem. Lett., 2227 (1990). b) W. Saka, Y. Inoue, Y. Yamamoto, R. Chujo, K. Takahashi, and K. Hattori, Bull. Chem. Soc. Jpn., 63, 3175 (1990). c) K. Takahashi, Y. Ohtsuka, S. Nakada, and K. Hattori, J. Incl. Phenomn. Mol. Recogn. Chem., 10, 63 (1991). d) K. Takahashi, J. Chem. Soc. Chem. Comm., 1991, 929. e) M. Akiyama, A. Kato, J. Kato, K. Takahashi, and K. Hattori, Chem. Lett., 1189 (1991). f) K. Takahashi, Bull. Chem. Soc. Jpn., 66, 540 (1993). g) K. Takahashi and K. Hattori, Supramol. Chem., 2, 305 (1993). h) K. Takahashi and R. Furusho, Polym. J., 28, 458 (1996).

11. F. D-Pilard, N. A-Bellanger, M. Gonsnat, D. Vernet, and B. Perly, J. Chem. Soc., Perkin Trans. 2, 1995, 723.

12. T. Kuwabara and A. Ueno, Supramol. Chem., 7, 235 (1996).

13. C. S. Wilcox, 'Design, Synthesis, and Evaluation of an Efficacious Functional Group Dyad. Methods and Limitations in the Use of NMR for Measuring Host-Guest Interactions', in "Frontiers in Supramolecular Organic Chemistry and Photochemistry", H-J. Schneider and H. Dürr, Ed., VCH, Weinheim, 1991, p 123.

14. A. Harada, H. Adachi, Y. Kawagachi, and M. Kamachi, Macromolecules, 30, 5181 (1997).

15. A. P. Demchenko, "Ultravioret Spectroscopy of Proteins", Springer-Verlag, London, 1981. 